\title{
ע Vapaaehtoistyöntekijöiden kokemuksia vastavuoroisuudesta ikääntyneiden ihmisten vapaaehtoistyössä
}

\author{
Irma Äyräväinen, Arja Piirainen, Taru Lintunen, Taina Rantanen \\ Jyväskylän yliopisto
}

\begin{abstract}
Sosiaalisen vaihdon teorioiden mukaan vastavuoroisuus on tärkeää ikääntyneiden ihmisten suhteissa. Vapaaehtoistyössä vastavuoroisuus on oleellista, mutta sitä ei ole juuri tutkittu eläkeikäisten vapaaehtoistyöntekijöiden kannalta. Tämän tutkimuksen tarkoituksena on selvittää, kuinka eläkeikäiset vapaaehtoistyöntekijät kokevat vastavuoroisuuden vapaaehtoistyössä. Kolme kuukautta kestäneen toimintajakson aikana vapaaehtoistyöntekijät auttoivat liikkumiskyvyn ongelmista kärsiviä ikäihmisiä osallistumaan kodin ulkopuoliseen toimintaan osana Vapaaehtoistyö, ulkoliikunta ja vanhusten hyvinvointi (VAU) -tutkimushanketta. Tämän laadullisen osatutkimuksen 17 osallistujaa olivat 61-72-vuotiaita. Tutkimusaineisto kerättiin yksilöhaastatteluilla ja analysoitiin aineistolähtöisellä sisällönanalyysillä. Eläkeikäiset vapaaehtoistyöntekijät kokivat saavansa vapaaehtoistyöstä sisältöä siirtymävaiheen elämäänsä ja antavansa inhimillisyyttä ikäihmisten vanhuuteen. Analyysissä saamisen yläkategorioiksi muodostuivat merkityksellinen toiminta, kasvu vanhenemiseen ja hyväksyvä ystävyys. Antamisen yläkategorioiksi saatiin avun antaminen, ajan antaminen, kuunteleminen ja arjen avartuminen. Symmetrisesti vastavuoroisuus tuli esiin hyväksyvässä ystävyydessä ja arjen avartumisessa, niissä yläkategorioissa molemmat osapuolet olivat samanaikaisesti sekä saavana että antavana osapuolena. Vapaaehtoistyön luonteeseen näyttää kuuluvan tällainen vastavuoroisuuden yhteen kietoutuneisuus, jossa saamista ja antamista on vaikea erottaa toisistaan. Sosiaalisen vaihdon vastavuoroisuus vaikuttaa toimivan vapaaehtoistyössä
\end{abstract}

\section{Johdanto}

Työelämän päättyminen eläkkeelle jäämiseen tuo eteen uusia kysymyksiä ajankäytöstä ja elämän uudelleen järjestämisestä. Vapaaehtoistyö on noussut yhdeksi tärkeäksi toimintamuo- doksi eläkkeellä olevien ihmisten elämässä. Eläkkeelle jääminen tuo muutoksia ihmisten vapaa-ajan käyttöön (Haarni 2010a; Casey 2014; Sabbath ym. 2016). Työssä käynnin loppuminen ja sen myötä lisääntynyt vapaa-aika antavat ihmisille uudenlaista vapautta valita, 
miten he haluavat aikaansa käyttää (Sabbath ym. 2016). Tutkimusten mukaan eläkkeelle jääminen on prosessi, jossa vähitellen jätetään työelämän roolit ja siirrytään eläkeläisen elämäntapaan. Tämä siirtyminen voidaan jakaa erilaisiin vaiheisiin, mutta tutkijoiden mukaan lopulta päädytään tyyntymiseen tai sopeutumiseen (Seitsamo 2007, 18), muutoksesta toivutaan ja siirtymästä seuraa asettuminen (Haarni 2010b, 40-41).

Taloustutkimuksen vuonna 2015 tekemän mielipidekyselyn mukaan joka kolmas suomalainen oli tehnyt vapaaehtoistyötä viimeisen neljän viikon aikana. Suomalaiset käyttävät vapaaehtoistoimintaan keskimäärin lähes 18 tuntia kuukaudessa, ja eniten aikaa vapaaehtoistyöhön käyttivät 65-79-vuotiaat, 23 tuntia neljässä viikossa (Rahkonen 2015). Vapaaehtoistyön tekeminen lisääntyy eläkeiässä, mutta ikä ei ole ainoa vaikuttava tekijä, koska toisaalta vapaaehtoistyön tekeminen vähenee terveyden heiketessä (Komp, van Tilburg \& Broese van Groenou 2012). Suomessa aikaisemmat tutkimukset eläkeikäisten vapaaehtoistyöstä ovat olleet kyselyjä vapaaehtoistyöhön osallistumisesta (Haarni 2010a) tai eläkeikäiset ovat olleet yksi ryhmä vapaaehtoistyötä tekevien joukossa (Yeung 2004). Lisäksi on tutkittu sitä, kuinka eläkeikäisten vapaaehtoistyöntekijöiden tekemä ulkoliikuntaan aktivoiva toiminta on vaikuttanut apua saaneiden ikäihmisten elämänlaatuun (Rantanen ym. 2015) ja masennusoireisiin (Rantakokko, Pakkala, Äyräväinen \& Rantanen 2014), sekä kuinka mielekkääksi vapaaehtoistyöntekijät ovat kokeneet tekemänsä työn (Räihä, Äyräväinen, Rantakokko, Lyyra \& Rantanen 2012). Eläkeikäisten ihmisten vapaaehtoistyötä koskevista tutkimuksista tehdyissä kansainvälisissä katsauksissa on keskitytty siihen, kuinka vapaaehtoistyön tekeminen vaikuttaa tekijöidensä hyvinvointiin (Wheeler, Gorey \& Greenblatt 1998; Onyx \& Warburton 2003; Corporation for National \& Community Service, Office of Research and Policy Development 2007; Gottlieb \&
Gillespie 2008; von Bonsdorff ja Rantanen 2011, Cattan, Hogg \& Hardill 2011).

Tämän tutkimuksen teoreettisena pohjana on vastavuoroisuus (reciprocity) sosiaalisen vaihdon teorian (social exchange theory) osana (ks. esim. Homans 1958; Emerson 1976; Blau 1987). Sosiaalisen vaihdon teoriaa voidaan pitää laajana viitekehyksenä, jonka sisällä eri suuntaukset keskustelevat keskenään (Emerson 1976). Näitä eri teorioita on käytetty paljon etenkin sosiologian, psykologian ja taloustieteiden tutkimuksissa. Vastavuoroisuutta pidetään tärkeänä osana sosiaalisen vaihdon teorioita ja sen katsotaan olevan avain myönteisiin tunteisiin sosiaalisessa kanssakäymisessä (Emerson 1976; Blau 1987). Sosiaalisen vaihdon teorioissa vastavuoroisuus ilmenee ihmisten välisten suhteiden rakentumisena ja jatkumisena paljolti sen mukaan, kuinka hyvin suhteeseen tehdyt panostukset ja palkinnot, antaminen ja saaminen, tasapainottuvat osapuolten välillä. Ihmissuhteissa ihmiset antavat ja saavat toinen toisiltaan erilaisia resursseja. Nämä resurssit voivat olla 1) materiaalisia, kuten rahaa, tavaroita tai palveluita, 2) emotionaalisia, jotka liittyvät tunteisiin, kuten rakkaus, huolehtiminen, asema ja kunnioitus tai 3) tiedollisia, kuten neuvot ja ohjeet, jotka voivat auttaa ongelmanratkaisussa (Emerson 1976; Blau 1987). Vastavuoroisuutta voidaan tarkastella kolmella eri tavalla: 1) vastavuoroisuus keskenään riippuvaisina vaihtoina 2) vastavuoroisuus kansan uskomuksena, ja 3) vastavuoroisuus moraalisena normina (Gouldner 1960). Tässä tutkimuksessa vastavuoroisuutta käsitellään saamisen ja antamisen vaihtoina osapuolten välillä.

Sosiaalisen vaihdon teorioiden valossa eläkeikäisten ihmisten ihmissuhteiden vastavuoroisuutta on aiemmin tutkittu ikääntyneiden ja heidän keski-ikäisten lastensa välillä (Liang ym. 2001; Fyrand 2010), pitkissä avioliitoissa (Tower \& Kasl 1996; Goodman 1999, Fyrand 2010), läheisissä ystävyyssuhteissa ikääntyneiden aikuisten kesken (Carlson Jones \& Vaughan 1990; Fyrand 2010), ikääntyneiden 
itsehoitoryhmissä (Grasser \& Craft 2000; Munn-Giddings \& McVicar 2007), formaalissa ja informaalissa hoivassa (Roe, Whattam, Young \& Dimond 2001; Wolff \& Agree 2004) sekä erittäin vanhojen hoivakodin asukkaiden suhteissa henkilökuntaan ja perheenjäseniin (Beel-Bates, Ingersoll-Dayton \& Nelson 2007). Viime vuosina vastavuoroisuutta on tutkittu esimerkiksi myöhäisellä iällä leskeksi jääneen vanhemman ja lapsien välisissä suhteissa (Isherwood, Luszcz \& King 2016) ja korostettu vastavuoroisuuden tärkeyttä suhteissa sosiaalityöntekijöiden ja hyvin vanhojen sekä hauraiden ihmisten kesken (Thompson 2016). Kaikissa näissä tutkimuksissa ihmisten välisissä suhteissa osallistujien pyrkimyksenä oli tasapainoinen vastavuoroisuus, ja epätasapainosta seurasi erilaisia ongelmia. Fyrand (2010) totesi katsauksessaan, jonka hän teki 20 tutkimuksesta, että ikääntyneiden ihmisten sosiaalisissa suhteissa epätasapaino kumpaan tahansa suuntaan vähensi elämän laatua ja heikensi mielenterveyttä.

Parhaiten vapaaehtoistyötä tekevien ja apua saaneiden ikäihmisten välisiä suhteita voidaan verrata läheisistä ystävyyssuhteista (Carlson Jones \& Vaughan 1990; Fyrand 2010) ja toisaalta ikääntyneiden itsehoitoryhmistä (Grasser \& Craft 2000; Munn-Giddings \& McVicar 2007) sekä informaalista hoivasta (Roe ym.2001; Wolff \& Agree 2004) tehtyihin tutkimuksiin. Lisäksi osa näistä tutkimuksista on tehty laadullisia tutkimusmenetelmiä käyttäen. Carlson Jonesin ja Vaughanin mukaan sosiaalisen vaihdon ei todettu vaikuttavan tyytyväisyyteen ystävyyssuhteissa. Sen sijaan heidän tutkimuksensa mukaan ystävyyssuhteen hyvinvointia näytti kasvattavan halukkuus ajatella muiden hyvinvointia ja toisten antaman tuen vastaanottamisen hyväksyminen. Heidän mukaansa näyttääkin siltä, että sosiaalisen vaihdon teoria ei välttämättä ole toimiva läheisissä ystävyyssuhteissa (Carlson Jones ja Vaughan, 1990). Fyrand taas totesi katsauksessaan, että ystävyyssuhteiden jatkuvuuden perustana näytti olevan osapuolten itsenäisyyden säilyminen, joka taas perustui tasapainoiseen vastavuoroisuuteen. Hänen katsauksessaan ystävyyssuhteet vaikuttivat myös olevan haavoittuvaisempia kuin puolisoiden tai vanhempien ja lasten väliset suhteet (Fyrand, 2010). Itsehoitoryhmiin osallistuneet ikäihmiset kokivat toisille antamisen tärkeäksi, mutta sen sijaan avun vastaanottaminen vaikutti lamaannuttavasti heidän toimintaansa (Grasser \& Craft 2000). Myös Roen kollegoineen 20 henkilölle tekemässä informaalia hoivaa koskevassa haastattelututkimuksessa on todettu ikäihmisille olleen vaikeaa pyytää ja vastaanottaa muiden antamaa apua. Vastavuoroisuuden todettiin parantavan ikäihmisten ja hoitohenkilöstön välistä suhdetta. Heidän tutkimuksessaan apua antaneista ihmisistä yli puolet oli perheenjäseniä tai vapaaehtoisia (Roe ym. 2001).

Laajoissa määrällisissä tutkimuksissa on havaittu koetun vastavuoroisuuden vapaaehtoistyössä ja epävirallisessa avussa lisäävän vapaaehtoistyötä tekevien hyvinvointia ja vastaavasti epäsuhtaisen vastavuoroisuuden alentavan hyvinvointia (esim. Wahrendorf ym. 2010). Vähäisen vastavuoroisuuden viimeisten työvuosien aikana on havaittu vähentävän ihmisten osallistumista vapaaehtoistyöhön eläkevuosiensa aikana (Wahrendorf, Blane, Matthews \& Siegrist 2016). Nämä tutkimukset ovat pääasiallisesti keskittyneet tutkimaan vastavuoroisuuden vaikutuksia tiettyihin muihin muuttujiin. On tutkittu vastavuoroisuuden epätasapainosta johtuvia kielteisiä vaikutuksia ja toisaalta vastavuoroisuuden tasapainosta johtuvia hyviä vaikutuksia esimerkiksi elämän laatuun, mielenterveyteen tai vapaaehtoistyöhön osallistumiseen. Vastavuoroisuus on ollut näissä tutkimuksissa mukana vain yhtenä muuttujana muiden joukossa, eikä sen taustaan tai rakentumiseen ole kiinnitetty huomiota. Tällainen tilastollinen tutkimus tuottaa tuloksia ilmiöiden yleisyydestä tai yhteyksistä toisiin tekijöihin, mutta niillä ei päästä itse vastavuoroisuuden ilmiön sisälle. Laadullisilla menetelmillä 
tehtyjä tutkimuksia aiheesta on hyvin vähän. Esimerkiksi Fyrandin (2010) tekemässä katsauksessa 20 tutkimuksesta vanhojen ihmisten sosiaalisista suhteista ei ollut mukana yhtään laadullisilla menetelmillä tehtyä tutkimusta. Omassa aikaisemmassa tutkimuksessamme selvitimme vastavuoroisuuden kokemuksia apua saaneiden ikäihmisten kannalta. Totesimme siinä, että liikkumiskyvyn ongelmista kärsivät ikäihmiset kokivat vastavuoroisuutta heitä auttaneiden eläkeikäisten vapaaehtoistyöntekijöiden kanssa (Äyräväinen, Lyyra, Lintunen \& Rantanen 2012). Useissa tutkimuksissa on havaittu vastavuoroisuuden vapaaehtoistyössä hyödyttävän sekä vapaaehtoistyöntekijöitä että apua saaneita henkilöitä (Onyx \& Warburton 2003), mutta tiedämme vain vähän vastavuoroisuudesta eläkeikäisten ihmisten keskinäisessä vapaaehtoistyössä.

Vuosina 2008-2011 Jyväskylän yliopisto ja Tutkimus- ja kehittämiskeskus GeroCenter järjestivät Jyväskylässä tutkimuksen, jossa eläkeikäiset vapaaehtoistyöntekijät auttoivat kodin ulkopuolisiin aktiviteetteihin sellaisia yksin asuvia ikäihmisiä, joilla oli vakavia liikkumiskyvyn ongelmia (Rantanen ym. 2015). Tässä tutkimuksessa tarkastellaan koettua vastavuoroisuutta vapaaehtoistyöntekijöiden kannalta. Artikkelissa on tarkoituksena kuvata ja ymmärtää, kuinka eläkeikäiset vapaaehtoistyöntekijät kokivat vastavuoroisuuden toimiessaan ikäihmisten kanssa.

\section{Aineisto ja menetelmät}

\section{Osallistujat}

Tähän tutkimukseen osallistuneet vapaaehtoistyöntekijät rekrytoitiin syksyn 2008 ja syksyn 2009 välisenä aikana. Vapaaehtoistyöntekijöiksi valittiin eläkkeellä olevia henkilöitä, joiden ohjaajat arvioivat soveltuvan hankkeeseen koulu- tusjakson aikana saamansa käsityksen perusteella. Tärkeintä oli kiinnostus ja sitoutuminen toimintaan. Toimintajakson alkaessa vapaaehtoistyöntekijä allekirjoitti suostumuksensa tutkimukseen osallistumisesta.

Kaikille vapaaehtoistyöntekijöinä toimiville järjestettiin kolmipäiväinen yhteensä 12 tuntia kestänyt koulutus. Perehdytyskoulutuksen aiheita olivat vapaaehtoistyöntekijänä toimiminen, turvallisuus ja hankkeeseen liittyvät oikeudet, velvollisuudet ja vastuut. Koulutuksessa harjoiteltiin käytännön vuorovaikutustilanteita toiminnallisia menetelmiä käyttäen Gordonin (2006) vuorovaikutusteorian mukaisesti. Teorian ydinosia ovat aktiivinen kuuntelu, selkeä itseilmaisu minä-viestejä käyttäen ja molemmat voittavat -menetelmä, jolla pyritään tasaarvoiseen ongelmanratkaisuun.

Perehdyttämisen jälkeen kukin vapaaehtoistyöntekijä tutustutettiin yhteen apua tarvitsevaan ikäihmiseen. He yhdessä suunnittelivat ikäihmisen kiinnostukseen pohjautuvan ohjelman, jonka pituus oli kolme kuukautta, ja joka suuntautui kodin ulkopuoliseen toimintaan. Kolmen kuukauden toimintajakson aikana vapaaehtoistyöntekijöillä oli ongelmatilanteissa mahdollisuus soittaa tutkimuskoordinaattorille. Lisäksi jokaisen toimintajakson aikana järjestettiin kolme työnohjauksellista ryhmätapaamista. Näissä tapaamisissa vapaaehtoistyöntekijät saivat vertaistukea, kun heillä oli mahdollisuus keskustella toiminnassa eteen tulleista tilanteista toistensa kanssa. Paikalla oli myös vapaaehtoistyön työnohjaukseen perehtynyt henkilö.

Tämän tutkimuksen aineistona olivat vapaaehtoistyötä tehneiden 17 eläkeikäisen henkilön (16 naista ja yksi mies) yksilöhaastattelut. Iältään he olivat 61-72-vuotiaita, keskiarvo oli 66,8 vuotta. Vapaaehtoistyöntekijöiden auttamien ikäihmisten ikäjakauma oli 70-90 vuotta ja keskiarvo 81 vuotta. 


\section{Haastattelut}

Vapaaehtoistyöntekijöiden yksilöhaastattelut tehtiin mahdollisimman pian heidän toimintajaksojensa päättymisen jälkeen. Haastattelut kestivät 25 minuutista 45 minuuttiin ja litteroitua tekstiä fonttikoolla 12 ja $1 \frac{1}{2}$ rivinvälillä kertyi 14-26 sivua haastattelua kohti, yhteensä 331 sivua. Haastattelurunko piti sisällään teemoja vapaaehtoistyön kokonaisuuden kokemisesta, toiminnan jatkamiseen liittyvistä tekijöistä sekä mitä haastateltavat olivat kokeneet saaneensa ja antaneensa toimintajakson aikana.

Jokaisessa yksilöhaastattelussa pyrittiin antamaan haastateltavalle tilaa puhua vapaasti hänelle tärkeistä asioista, häntä ei keskeytetty eikä palautettu haastattelurungon mukaiseen järjestykseen (Lumme-Sandt 2005). Kuitenkin huolehdittiin siitä, että kaikki teemat tulivat käsitellyiksi. Haastatteluista kaksitoista tehtiin haastateltavien kotona ja viisi yliopiston tiloissa. Tulososassa käytettyjen aineistolainauksien murresanoja on muutettu yleiskielelle tunnistettavuuden estämiseksi. Sairaanhoitopiirin eettinen toimikunta on antanut tutkimukselle myönteisen lausunnon.

\section{Analysointi}

Aineisto analysoitiin käyttämällä aineistolähtöistä, luokittelevaa sisällönanalyysia, jossa tarkasteltiin vastavuoroisuutta apua saaneen ikäihmisen kanssa (Schreier 2012, 89). Aineiston analyysi aloitettiin lukemalla kirjoitettua tekstiä ja kuuntelemalla haastattelunauhoja useita kertoja, mikä mahdollisti pääasioiden ja tutkimuskysymysten kannalta oleellisten asiakokonaisuuksien tunnistamisen. Teksti käytiin läpi etsien vastavuoroisuutta, antamista ja saamista. Alkuperäisilmauksista jokainen toteamus pelkistettiin tiiviimpään muotoon. Aineiston järjestely, alkuperäisilmausten pelkistäminen ja ryhmittelyt tehtiin käsityönä. Pelkistetyistä ilmauksista muodostuivat alakategoriat, jotka nimettiin mahdollisimman kuvaavasti ja kattavasti (Taulukko 1). Tässä vaiheessa palattiin usein takaisin alkuperäiseen tekstiin tarkistamaan, että tulkinta pohjautui mahdollisimman hyvin alkuperäisilmaukseen ja asiayhteyteen. Jatkossa samansisältöisiä alakategorioita yhdistettiin toisiinsa ja muodostettiin niistä yläkategorioita, joille annettiin niiden sisältöä kuvaavat nimet (Taulukko 1). Yläkategorioita yhdistävät pääkategoriat nimettiin Sisältöä siirtymävaibeen elämään ja Inbimillisyyttä vanhuuteen. Analyysin viimeisessä vaiheessa kummankin pääkategorian sisältä yksi yläkategorioista osoittautui vastavuoroisuutta kuvaavaksi (Taulukko 2) (Schreier 2012, 37-44).

Autenttisia lainauksia käytetään havainnollistamaan alakategorioita. Aineisto-otteiden lopussa oleva kirjain kuvaa haastateltavaa ja numero ikää vuosina sekä toinen numero litteraation sivunumeroa.

\section{Tulokset}

Eläkeikäisten vapaaehtoistyöntekijöiden kokemuksista vastavuoroisuudesta syntyi kaksi yksisuuntaista vastavuoroisuutta kuvaavaa pääkategoriaa vapaaehtoistyöntekijöiden saamisesta ja antamisesta: vapaaehtoistyöntekijät saivat sisältöä siirtymävaiheen elämään ja antoivat inbimillisyyttä vanhuuteen. Lisäksi näiden pääkategorioiden sisältä löytyi kaksi kaksisuuntaista vastavuoroisuutta kuvaavaa yläkategoriaa: Hyväksyvä ystäryys ja Arjen avartuminen. Eläkeikäisten vapaaehtoistyöntekijöiden yksilöhaastatteluista kerättyjen litteroitujen tekstien analyysin tuloksena muodostuivat yläkategoriat ja niitä kuvaavat alakategoriat. Seuraavaksi käsitellään näitä tuloksia yläkategorioittain. 
Taulukko 1. Analyysissä muodostettu kategorisointi

\begin{tabular}{|c|c|c|}
\hline Alakategoriat & Yläkategoriat & Pääkategoriat \\
\hline A1a) Tarpeellisuuden kokemus & \multirow{4}{*}{ A1) Merkityksellinen toiminta } & \multirow{11}{*}{$\begin{array}{c}\text { A) Sisältöä sïrtymävaiheen } \\
\text { elämään }\end{array}$} \\
\hline A1b) Tapaamisten merkityksellisyys & & \\
\hline A1c) Vapaaehtoistyön arvostaminen & & \\
\hline A1d) Oman elämän aktivoituminen & & \\
\hline A2a) Itsetuntemuksen lisääntyminen & \multirow{2}{*}{ A2) Kasvu vanhenemiseen } & \\
\hline A2b) Vanhenemiseen valmentautuminen & & \\
\hline A3a)Vapaaehtoissuhteen rakentuminen & \multirow{5}{*}{ A3 )Hyväksyvä ystävyys } & \\
\hline A3b) Vuorovaikutuksellisuus & & \\
\hline A3c) Luottamuksellinen ystävyyden ilmapiiri & & \\
\hline A3d) Eettinen hyvän tekeminen & & \\
\hline A3e) Vapaaehtoissuhteen säilyminen & & \\
\hline B1a) Asiointiapua & \multirow{4}{*}{ B1) Avun antaminen } & \multirow{12}{*}{ B) Inhimillisyyttä vanhuuteen } \\
\hline B1b) Avustaminen & & \\
\hline B1c) Omatoimisuutta arkeen & & \\
\hline B1d) Liikkumisapua & & \\
\hline B2a) Vain aikaa - saan jotain enemmän & \multirow{2}{*}{ B2) Ajan antaminen } & \\
\hline B2b) Oman ajan antaminen & & \\
\hline B3a) Puhuminen & \multirow{3}{*}{ B3) Kuunteleminen } & \\
\hline B3b) Toisen kuunteleminen & & \\
\hline B3c) Luotettava toisen kuuntelija & & \\
\hline B4a) Arkirutiinin kohokohta & \multirow{3}{*}{ B4) Arjen avartuminen } & \\
\hline B4b) Virkistävä ihmissuhde & & \\
\hline B4c) Kulttuurikokemuksia & & \\
\hline
\end{tabular}

\section{A) Vapaaehtoistyöntekijät saivat sisältöä siirtymävaiheen elämään}

Haastateltavat kertoivat runsaasti tuntemuksiaan siitä, kuinka he kokivat saaneensa sisältöä siirtymävaiheen elämäänsä toimiessaan vuorovaikutuksessa ikäihmisen kanssa. Vapaaehtoistyöntekijät kokivat tärkeäksi sen, että olivat löytäneet uutta merkityksellistä tekemistä elämäänsä eläkkeelle jäämisen jälkeen. Haastateltavat tunsivat myös kehittyneensä ja kasvaneensa vanhenemisessa, kun saivat opastusta ja mentorointia vanhenemisen kokemusasiantuntijoilta, kauemmin eläkkeellä olleilta ikäihmisiltä. Kaksisuuntaista, symmetristä vastavuoroisuutta vapaaehtoistyöntekijät kokivat hyväksyvän ystävyyden muodostumisessa ja jatkumisessa. Tätä sisältöä siirtymävaiheen elämään -pääkategoriaa (A) kuvaaviksi yläkategorioiksi nousivat $\mathrm{A} 1$ ) merkityksellinen toiminta, A2) kasvu vanhenemiseen ja A3) hyväksyvä ys- tävyys. Kukin yläkategoria muodostui useammasta yläkategoriaa kuvaavasta alakategoriasta.

\section{A1) Merkityksellinen toiminta}

Merkityksellisen toiminta -kategoriaan sijoittuivat vapaaehtoistyöntekijöiden kokemukset tarpeellisuudesta niille ikäihmisille, joita he kävivät tapaamassa. He kertoivat tapaamisten merkityksellisyydestä, ja siitä, kuinka ikäihmiset odottivat heitä ja kuinka he itse odottivat tapaamisia ikäihmisen kanssa. Lisäksi vapaaehtoistyö tuntui vapaaehtoistyöntekijöistä kuin paluulta kaivattuun työelämään ja vapaaehtoistyön myötä heidän oma elämänsä aktivoitui muutenkin. Merkityksellinen toiminta ilmeni toisaalta tarpeellisuuden kokemuksena ja toisaalta kokemuksena vapaaehtoistyön tekemisen arvostuksesta. Tarpeellisuuden kokemuksen (A1a) -alakategoriaan sijoittui se, että useampi kuin puolet haastatelluista vapaa- 
ehtoistyöntekijöistä kertoi, kuinka he saivat kokea olevansa tarpeellisia tai hyödyllisiä toimiessaan vapaaehtoistyössä. Kuten yksi heistä mainitsi:

Se tuntuu tarpeelliselta ja tuota koen, että en ole vielä yhteiskunnassa sivuraiteilla, että on jotakin virkaa ja jotakin älykästä ja tarpeellista on saanut aikaan. (A 63,15$)$

Moni vapaaehtoistyöntekijä kertoi, kuinka ikäihminen vastaanotti heidät ilmaisten ilonsa tapaamisesta tai odotti, että he tekevät jotain yhdessä (A1b). Eräs heistä kuvasi kuinka:

Se oli hyvin aina lämmin halaus aina se vastaanotto joka kerta. (S 71, 7).

Odottaminen oli molemminpuolista. Osa haastatelluista vapaaehtoistyöntekijöistä kertoi odottavansa tapaamista viikon kohokohtana tai olevansa pettynyt tapaamisen peruuntumisesta. Yksi heistä kuvaili:

Minäkin olen kokenut sen virkistävänä. Ne ovat mieluisia hetkiä nämä ja olen ihan mielelläni aina lähtenyt ja mennyt ja järjestänyt tämän tapaamisen. (R 70, 4)

Vapaaehtoistyön arvostaminen (A1c) ilmeni kokemuksissa paluusta kaivattuun työelämään, työn onnistumisen kuvauksina ja haluna saada seurata ikäihmisen selviytymistä mahdollisimman pitkään. Joku koki nyt löytäneensä jotain sellaista, mitä oli etsinyt. He kertoivat kuinka:

Se on ollut yksi lisä tässä minun elämässäni sillä tavalla, että se on täyttänyt [elämää]. Tai minä olen löytänyt sellaista, mitä minä olen sitten hakenutkin. (K 66, 11).

Jotenkin palaa niin kuin tämä aikaisempi elämä. Työ, se mitä olen kaivannut, mikä jäi kesken. (R 70,4)
Oman elämän aktivoituminen (A1d) ilmeni siten, että vapaaehtoistyöntekijät kokivat saavansa omaan elämäänsä vapaaehtoistapaamisten kautta ryhdikkyyttä ja rytmiä monella tapaa. Vapaaehtoistyöntekijät kokivat aktivoituneensa itsekin, päässeensä johonkin kiinni ja heidän tuli lähdettyä liikkeelle. Eräs heistä mainitsi:

Kun lähtee tällä tavalla mukaan, niin itsellekin tulee sellainen hyvä mieli ja tulee aktiivisemmaksi kai joka suhteessa. (R 67, 10)

\section{A2) Kasvu vanhenemiseen}

Kasvu vanhenemiseen yläkategoriaan sisältyi kahdenlaisia kokemuksia. Vapaaehtoistyöntekijät kokivat saaneensa lisää itsetuntemusta, ja toisaalta he kertoivat siitä, kuinka olivat saaneet esimerkin vanhenemisesta apua saaneelta ikäihmiseltä. Vapaaehtoistyöntekijät mainitsivat, kuinka he olivat kokeneet uusia asioita, saaneet uusia ajatuksia, muuttaneet ajattelutapaansa, löytäneet uusia näkökulmia ja oppineet oman pohdintansa kautta (A2a). Eräs heistä kertoo:

On oppinut pitämään kielensä kurissa, että ei ole sanonut kuitenkaan, että kyllä olisi hyvä, kun täällä olisi enemmän valoa ja olen oppinut pitämään kaikki sellaiset sisälläni. (T 61, 13)

Vapaaehtoistyöntekijät kokivat myös saaneensa tapaamiltaan ikäihmisiltä elämänkokemuksia tai esimerkkiä myönteisestä elämänasenteesta, ja he olivat oppineet ennakointia omaa tulevaisuuttaan ajatellen (A2b). Kuten yksi haastatelluista mainitsi:

Kuullut hänen elämänkokemuksiaan ja niistä aina, aina oppii ja sitten, niin kuin oman vanhenemisensa varalle. $(\mathrm{R} 70,15)$ 


\section{A3) Hyväksyvä ystävyys}

Kaksisuuntaista vastavuoroisuutta kuvaavassa Hyväksyvän ystävyyden -yläkategoriassa toiminnan molemmat osapuolet olivat mukana tasapuolisina toimijoina, jotka yhdessä rakensivat suhdetta eteenpäin. Vapaaehtoistyöntekijät korostivat puheissaan suhteen vastavuoroisuutta, vuorovaikutuksellisuutta, eettisyyttä, ja vapaaehtoisuutta. He kertoivat siitä, kuinka vapaaehtoissuhde alkoi rakentua kullakin parilla omalla tavallaan. Haastateltavat puhuivat siitä, miten vuorovaikutuksellisuus toimi ja vaikutti toiminnan jatkumiseen. He kuvailivat sitä, kuinka vähitellen tapaaminen tapaamiselta rakentui molemminpuolinen luottamuksen ilmapiiri. Vapaaehtoistyöntekijät kertoivat sitä, kuinka hyvän mielen tuntemuksia koettiin puolin ja toisin. Vapaaehtoistyöntekijät puhuivat siitä, kuinka yhteisen tekemisen myötä toisen toimintatavat tulivat tutuiksi ja mieleisiksi, ja näin suhteen jatkuvuus varmistui. Yli puolet haastatelluista kertoi kokemuksiaan vapaaehtoissuhteen rakentumisesta, kuinka tutustuminen uuteen ihmiseen lähti liikkeelle yhteisistä asioista, henkilökemiasta tai kahvien tarjoamisesta (A3a). Eräs haastatelluista kuvaili:

Huomasin sanovani hänelle aika reippaasti jotain ja hän myös minulle, ettei me arasteltu toisiamme yhtään. Että me olimme kuin vanhat tutut sitten jo. (A 68,14$)$

Vapaaehtoistyöntekijät kertoivat kuuntelemisesta, keskusteluista ja mielipiteiden vaihtamisesta. Kuten yksi heistä mainitsi:

Sitten nämä keskustelut olivat tosiaan, että ne olivat mielenkiintoisia. (A 63, 3)

Haastatteluista nousi esiin kuvauksia syvästä ihmissuhteesta, ystävyydestä ja molemmin puolisesta luottamuksesta. Eräs tutkittavista kertoi:
Olen saanut hänen luottamuksensa ja tuota semmoisen mukavan, arvokkaan vanhan rouvan ystävyyden. (K 66, 11)

Vapaaehtoistyöntekijät olivat kokeneet tuoneensa toiminnallaan hyvää mieltä apua saaneelle ikäihmiselle sekä itselleen (A3d). Kuten yksi haastatelluista sanoi:

Mutta se on ihan ilontunnetta, mitä minulla sitten hänen kanssaan on ollut. (S 65, 3)

Vapaaehtoistyöntekijät kuvailivat apua saaneen ikäihmisen miellyttäviä luonteenpiirteitä, hänen tapaansa toimia ja suhteen toimivuutta (A3e). Erään haastatellun sanoin:

Niin hän tuntui kaiken tämmöisen ymmärtävän.. että ei ole semmoinen ruikuttava. (A 68, 6)

\section{B) Vapaaehtoistyöntekijät antoivat inhimillisyyttä vanhuuteen}

Vapaaehtoistyöntekijöiden haastatteluissa tuli esille kokemuksia siitä, kuinka he kokivat antaneensa inhimillisyyttä ikäihmisten vanhuuteen toimiessaan vuorovaikutuksessa heidän kanssaan. Vapaaehtoistyöntekijät kokivat tuoneensa inhimillisyyttä ikäihmisten elämään antamalla konkreettisesti käytännöllistä apua. Ajan antaminen koettiin tärkeäksi, samoin ikäihmisen kuunteleminen. Kaksisuuntaista vastavuoroisuutta vapaaehtoistyöntekijät tunsivat, kun he kokivat avartaneensa ikäihmisten arkea ja samaan aikaan heidän oma arkensa avartui uusien yhteisten kokemusten ansiosta. Tätä inbimillisyyttä vanhuuteen -pääkategoriaa kuvaaviksi yläkategorioiksi muodostuivat B1) avun antaminen, B2) ajan antaminen, B3) kuunteleminen ja B4) arjen avartuminen.

\section{B1) Avun antaminen}

Avun antamisen -yläkategoriassa vapaaehtoistyöntekijät kertoivat, kuinka he antoivat apuaan 
ikäihmisten hoitaessa itselleen tarpeellisia kodin ulkopuolisia asiointeja. He puhuivat siitä, kuinka he avustivat ikäihmisiä myös monissa käytännön asioissa kotona tai ulos lähtemisessä. Samoin haastateltavat kuvailivat sitä, miten he mahdollistivat ikäihmisten itsenäistä toimintaa, ja miten he auttoivat heitä liikkumisen ongelmissa ulkona kuljettaessa. Vapaaehtoistyöntekijät kuvailivat antamaansa apua, jonka turvin ikäihmiset pääsivät hoitamaan heille tärkeitä asioita pankkiin, apteekkiin tai kauppaan (B1a). Eräs haastatelluista kertoi:

Mutta sitten niin kuin tällaisia, jonne tarvitsi, kävelymatkan päässä oli jotakin, niin sitten halusi apua niihin. ( $\mathrm{R}$ 67, 3)

Vapaaehtoistyöntekijät kertoivat, kuinka antoivat käytännön apua, lukivat lehtiä, nostivat pyörällisen kävelytelineen ja opettivat uuden laitteen käytössä (B1b). Kuten yksi heistä sanoi:

Kun hän tarvitsee välttämättä sen apurin siinä kun on kahdeksan porrasta, jotka on nostettava se rollaattori. Hän on niin heikkovoimainen, että ei millään pysty. (A 69,14)

Omatoimisuutta arkeen (B1c) -alakategoriaan sijoittui se, kuinka apua saaneet ikäihmiset olivat saaneet, vapaaehtoistyöntekijöiden kanssa, hoitaa omia asioitaan rauhassa tai päässeet käymään kaupassa omilla ehdoillaan. Tähän kategoriaan sisältyi myös se, kuinka ikäihminen oli päässyt itse valikoimaan kaupassa mieleisiään tuotteita tai kuinka hän oli saanut mahdollisuuden tarjota kahvit kotonaan. Apua saaneelle ikäihmiselle annettiin mahdollisuus päästä kiinni elämään, kun hän sai tehdä elämäänsä aikaisemmin kuuluneita asioita. Eräs haastateltavista vapaaehtoistyöntekijöistä kuvasi tilannetta:

Mutta kyllä nämä, ihan nämä kaupassakäynnitkin niin tuota. Kyllä siinäkin jo, että se tapahtuu sen autettavan omilla ehdoilla se kaupassa käyminen. Niin kyllä sekin on aika kiva. Että ei yhtään oltu muualla kun lamppukaupassa, kauppa missä on älyttömästi tavaraa. Jo semmoisessa kaupassa, hän oli tosi iloinen, että hän sai olla siellä rauhassa. Ja valita sitten. (S 65, 14-15)

Ulkona liikkuminen oli yksi hankkeen tavoitteista ja vapaaehtoistyöntekijät olivat ottaneet sen todella sydämensä asiaksi (B1d). Monelle ikäihmiselle pieni lenkki kodin lähiympäristössä oli jo paljon. Yhdessä tapauksessa apua saaneella henkilöllä oli koira,jota ulkoilutettiin sitten yhdessä vapaaehtoistyöntekijän kanssa. Eräs vapaaehtoistyöntekijä kertoi:

No, varmaan juuri se, että hän pääsi ulos, pääsi niin kuin ihmisten ilmoille. (T 61,14)

\section{B2) Ajan antaminen}

Ajan antamisen yläkategoriassa haastateltavat puhuivat toisaalta siitä, miten he antoivat vain aikaa, mutta saivat paljon enemmän, mutta toisaalta he puhuivat siitä, miten he antoivat omaa aikaansa. Haastateltavat kertoivat kokemuksiaan siitä, kuinka antoivat mielestään vain vähän, verrattuna siihen miten paljon he kokivat saavansa toiminnasta (B2a). He puhuivat siitä, kuinka aikaa on paljon, mutta että heidän ei kuitenkaan tullut käytettyä auttamistoimintaan mielestään riittävästi aikaa. Tai he mainitsivat, kuinka he toisaalta kokivat, etteivät toimineet auttamisessa riittävän tehokkaasti. Kuten eräs kuvailee:

No kyllähän minä enemmän olen saanut kuin antanut. Että tuota, onhan se ollut niin mielenkiintoista ja sitten enhän minä ole antanut kuin aikaani. ( $\mathrm{T} 61,14$ )

Monet haastateltavat kertoivat antavansa aikaansa tai omaa aikaa (B2b). Toiset vapaaehtoistyöntekijät taas mainitsivat konkreettisen aikamäärän tai sen ettei ole kiirettä. Seuraavaksi kaksi esimerkkiä haastatteluista: 
No minä olen tietenkin antanut omaa aikaani. (A 63, 16)

Minulla menee niin monta tuntia aina siellä. Minä jotenkin en henno lähteä sieltä pois, kun minä tiedän, että toinen puhuu minulle aina vaan... niitä asioita. Niin ei minulla ole mikään kiire. (A 67,24)

\section{B3) Kuunteleminen}

Kuuntelemisen yläkategoriassa haastateltavat kertoivat, kuinka heidän puhettaan haluttiin kuunnella tai kuinka he kuuntelivat toista ja kuinka luotettavaksi kuuntelijaksi heidät koettiin. Yksi vapaaehtoistyöntekijä kertoi siitä, kuinka hänen autettavansa kuunteli mielellään hänen puhettaan (B3a). Hän mainitsi:

Minullehan on aina sanottu, että minä olen vähän semmoinen liian puhelias, mutta en minä tiedä. Mutta tuo Anni ainakin tykkäsi juuri siitä, että kun hän sanoi, että on kiva kuunnella. (T 67,11)

Moni vapaaehtoistyöntekijä kuvaili sitä, kuinka toiminnan oleellinen osa oli olla ikäihmisen kuuntelijana (B3b). Eräs heistä kertoi:

Mutta sitten, kyllä hän on niitä omia tuntojaan, ihan siitä sen tämän hetkisestä elämäntilanteesta puhunut kovasti ja, ja surrut ja ollut huolissaan siitä, että miten tämä kehittyy ja. Ja joskus, että jokohan tämä oli viimeinen päivä kun näin ja näin. Kaikkea, että kyllähän siellä on semmoinen suru ja huoli ja yksinäisyys asioista. Ja sitten sieltä on tullut semmoista. Ja kaipa se on kaikista tärkein, että on jotenkin niin kuin kyennyt kuuntelemaan sitä ja kuulemaan sitä viestiä. (K 66, 6)

Oman alakategoriansa muodostivat maininnat luottamuksellisesta toisen kuuntelijasta (B3c), jolloin kuuntelemisen yhteydessä mainittiin luottamuksellisuus tai ulkopuolinen, objektii- vinen kuuntelija. Eräs vapaaehtoistyöntekijä kertoi:

Kun saa puhua, kyllä ja tämmöiselle niin kuin vieraalle ihmiselle, jolla ei ole mitään, niin mitään sidettä niihin asioihin. (I 71, 12)

\section{B4) Arjen avartuminen}

Kaksisuuntaista vastavuoroisuutta kuvaavassa Arjen avartuminen -yläkategoriassa vapaaehtoistyöntekijöiden puheessa ilmeni, kuinka antamisen ohella he samanaikaisesti saivat ikäihmisiltä. Vapaaehtoistyöntekijät kertoivat siitä, kuinka ikäihmisten luona käynti muodosti kohokohdan molempien päivään. He puhuivat siitä, kuinka uusi ihmissuhde innosti ja antoi uusia kokemuksia molemmille. Vapaaehtoistyöntekijät kertoivat kokemuksiaan siitä, kuinka tarjosivat yksinasuvan ikäihmisen elämään vaihtelua, virikkeitä, väriläiskää ja jotain odotettavaa (B4a). Erään haastateltavan sanoin:

Kyllä minä uskon, että jonkin näköistä virkistystä ja mielenkiintoa. (T 61, 14)

Apua saaneen ikäihmisen arki avartui vapaaehtoistyöntekijän antaman virkistävän ihmissuhteen (B4b) jopa vastavuoroisen ystävyyden kautta. Haastatteluissa kerrottiin yhteiset hauskat jutut ja siitä, kuinka ikäihminen oli innostunut uusista asioista. Monet mainitsivat uuden keskustelukumppanin ja keskustelujen tuovan vaihtelua ja uusia näkökulmia ikäihmisen elämään. Kuten eräs heistä kuvaili:

No, tuulahduksen toisenlaisesta elämänpiiristä tai siitä vähän nuoremmasta elämänpiiristä. $(\mathrm{K} 66,12)$

Kulttuurikokemuksien antaminen (B4c) muodostui vapaaehtoistyöntekijöiden kertomuksista erilaisista arkirutiinit katkaisevista, uudenlaisista toiminnoista. Uuteen paikkaan tutustu- 
Taulukko 2. Yläkategoriat jaoteltuina yksisuuntaiseen saamiseen, kaksisuuntaiseen vastavuoroisuuteen ja yksisuuntaiseen antamiseen.

\begin{tabular}{|c|c|c|}
\hline $\begin{array}{c}\text { Yksis uuntainen } \\
\text { vas tavuorois uus, saaminen }\end{array}$ & $\begin{array}{c}\text { Kaksis uuntainen } \\
\text { vastavuorois uus }\end{array}$ & $\begin{array}{c}\text { Yksis uuntainen } \\
\text { vas tavuorois uus, antaminen }\end{array}$ \\
\hline A1 Merkityksellinen toiminta & & B1 Avun antaminen \\
\hline A2 Kasvu vanhenemiseen & & B2 Ajan antaminen \\
\hline & A3 Hyväksyvä ystävyys & B3 Kuunteleminen \\
\hline & B4 Arjen avartuminen & \\
\hline
\end{tabular}

minen ja pääsy esimerkiksi torille, rautakauppaan tai hautausmaalle olivat yksilöllisiä, ikäihmisten omien kiinnostusten mukaisia kohteita. Perinteisinä kulttuurikokemuksina mainittiin museot, teatterit, konsertit ja taidenäyttelyt. Kuten yksi haastatelluista kertoi:

No, ihan sitä, että nämä oli nämä museokäynnit ja ylipäätänsä niin tuota, sanotaanko nyt taiteesta keskusteleminen ja semmoinen, niin se oli hänelle, niin tavallaan uutta. (R 72, 12)

Tuloksista muodostuivat vastavuoroisuutta kuvaavat yläkategoriat: yksisuuntaisesta vastavuoroisuudesta kertovat antaminen ja saaminen, sekä kaksisuuntaista vastavuoroisuutta kuvaava vastavuoroisuus. Yksisuuntaisten, saamisen ja antamisen, yläkategorioiden joukosta erottui kaksi kaksisuuntaista vastavuoroisuutta kuvastavaa kategoriaa: byväksyvä ystäryys saamisen puolella ja arjen avartuminen antamisen puolella. Näissä kategorioissa ilmenivät ja korostuivat vapaaehtoistoimintaan oleellisesti kuuluvat piirteet. Ne ovat kohtia, joissa vapaaehtoistyöntekijä ja toisena osapuolena oleva ikäihminen olivat symmetrisessä vastavuoroisessa suhteessa, molemmat ovat samanaikaisesti sekä antavana että saavana osapuolena. Katso taulukko 2.

\section{Pohdinta}

Tässä tutkimuksessa tarkasteltiin vastavuoroisuutta vapaaehtoistyössä eläkeikäisten vapaaehtoistyöntekijöiden kokemana. Vastavuoroisuuden tarkastelu tuotti yksisuuntaisen saamisen kokemuksia kuvaavan sisältöä siirtymävaiheen elämään -pääkategorian ja sitä kuvaavat yläkategoriat merkityksellinen toiminta, kasvu vanhenemiseen ja byväksyvä ystävyys ja yksisuuntaisen antamisen kokemuksiin liittyen inbimillisyyttä vanhuuteen -pääkategorian ja sitä kuvaavat yläkategoriat avun antaminen, ajan antaminen, kuunteleminen ja arjen avartuminen. Näistä yläkategorioista saamista kuvaava byväksyvä ystäryys ja antamista kuvaava arjen avartuminen osoittautuivat analyysin viimeisessä vaiheessa lopulta kaksisuuntaiseksi vastavuoroisuudeksi, joissa saaminen ja antaminen tapahtuvat samanaikaisesti.

Tutkimuksen tulokset toivat lisää tietoa aiempaan tietämykseen aiheesta (vrt. Merrell 2000; Fyrand 2010; Wahrendorf ym. 2010; Zaninotto, Breeze, McMunn \& Nazroo 2013). Tutkimuksemme mukaan vapaaehtoisina toimivat eläkeikäiset ihmiset kokivat vastavuoroisuutta liikkumiskyvyn ongelmista kärsivien ikäihmisten kanssa toimiessaan. He kokivat toisaalta saavansa sisältöä siirtymävaiheen elämäänsä ja toisaalta antavansa inhimillisyyttä ikäihmisten vanhuuteen. Nämä 
erilliset saamisen ja antamisen kokemukset tasapainottuivat vapaaehtoisten tuntemuksissa vastavuoroisuudeksi (Emerson 1976; Blau 1987). Samansuuntaisia tuloksia ovat saaneet Zaninotto ym. (2013) tutkiessaan pitkittäistutkimuksessaan eläkeikää lähestyvien vastavuoroisuutta ja hyvinvointia vapaaehtoistyötä tekevien keskuudessa. Heidän tutkimuksessaan vastavuoroisuus vapaaehtoistyössä ennusti korkeampaa elämän laatua ja pienempää todennäköisyyttä masentumiselle.

Eläkeikäisten vapaaehtoistyöntekijöiden kokemasta vastavuoroisuudesta yksin kotonaan asuvien ikäihmisten kanssa löytyi uusia piirteitä, joita emme löytäneet aikaisemmista tutkimuksista. Tosin pelkästään eläkeikäisten tekemän ja eläkeikäisiin kohdistuvan vapaaehtoistyön vastavuoroisuutta käsittelevää tutkimusta ei ole aikaisemmin tehty. Tässä tutkimuksessa löytyi kaksi yläkategoriaa, jotka nimesimme kaksisuuntaiseksi, symmetriseksi vastavuoroisuudeksi (ks. Emerson 1976). Niissä, vapaaehtoistyötä tekevien vapaaehtoisten kokemusten mukaan, he olivat samanaikaisesti sekä antavana että vastaanottavana osapuolena. Vastavuoroisuus toteutui molemminpuolisena byväksyvä ystävyys ja arjen avartuminen -yläkategorioissa. Hyväksyvän ystävyyden -yläkategoria näyttäytyi ensin yksisuuntaisena saamisena: vapaaehtoistyöntekijät kokivat saavansa ikäihmisiltä. Mutta myöhemmin paljastui, että kyseessä oli vapaaehtoistyölle tyypillinen, molemminpuolinen, kaksisuuntainen vastavuoroisuus: vapaaehtoissuhteen molemmat osapuolet olivat siinä mukana antaen ja saaden samanaikaisesti.

Hyväksyvässä ystävyydessä rakentui vapaaehtoissuhde, missä vallitsi vuorovaikutuksellisuus ja luottamuksellinen ilmapiiri. Molemmat osapuolet kokivat tekevänsä eettisesti hyvää, ja ylläpitävänsä omalla toiminnallaan vapaaehtoissuhdetta. Kaksisuuntaista, symmetristä vastavuoroisuutta ilmensi myös Arjen avartuminen -yläkategoria. Se sisälsi kokemuksia arkirutiinin kohokohdista, uudesta ihmissuhteesta ja kulttuurikokemuksista. Tämä kategoria vaikutti aluksi siltä, että vapaaehtoiset yksi- puolisesti toivat näitä asioita ikäihmisen arkeen. Lähempi tarkastelu osoitti, että samalla vapaaehtoistyöntekijät kokivat vastaavasti saavansa samoja asioita omaan elämäänsä. Erityisen hyvin kaksisuuntainen vastavuoroisuus ilmeni kulttuurikokemusten jakamisessa. Vapaaehtoistyöntekijät mahdollistivat ikäihmisille näihin kulttuurikokemuksiin pääsyn, mutta samanaikaisesti idea tai toive niihin tuli useimmiten ikäihmiseltä itseltään ja näin ikäihmiset ikään kuin opastivat vapaaehtoisia uusien kokemusten äärelle.

Tuloksissamme tärkeäksi nousi vastavuoroisuuden tuoma sisältö vapaaehtoistyöntekijöiden siirtymävaiheen elämään. Samoin Haarni (2010b, 35), joka on tutkinut eläkeläisten työiän jälkeistä elämää osallistumisen ja vapaaehtoistoiminnan näkökulmasta, totesi eläkkeelle jäämisen toimivan monilla ihmisillä vapaaehtoistyön pontimena. Tutkimuksessaan hän havaitsi eläkeikäisten täyttävän elämänsä itselleen mieluisilla ja mielekkäillä asioilla (Haarni 2010b, 50). Tutkimuksessamme merkityksellisen toiminnan yhtenä alakategoriana oli vapaaehtoistyön arvostaminen tietynlaisena työn jatkumisena, ja myös Haarnin (2010b) tutkimuksessa haastateltavat etsivät itselleen työtä korvaavaa tekemistä palkkatyön jäätyä pois. Toisaalta aikaisemmissa kansainvälisissä vapaa-aikaan liittyvissä tutkimuksissa on huomattu vastavuoroisuuden merkitys. Koetun vastavuoroisuuden uuden toiminnan mukanaan tuomien ihmisten kanssa on todettu lisäävän kiinnostusta toiminnan jatkumiseen (Searle 1989; Auld \& Case 1997).

Tämän tutkimuksen tuloksista löytyi paljon vastaavuuksia verrattuna aikaisempaan tutkimukseemme apua saaneiden ihmisten kokemuksista vastavuoroisuudesta (kts. Äyräväinen ym. 2012). Nämä yhdenmukaisuudet vahvistivat vastavuoroisuuden molemminpuolisuutta. Samoja asioita löytyi molempien osapuolten kokemuksista. Vapaaehtoistyöntekijöiden saamisena kokemat asiat tulivat esiin ikäihmisten antamisen kokemuksina, ja vastaavasti ikäihmisten saamisen kokemukset taas vapaa- 
ehtoistyöntekijöiden antamisen kokemuksina.

Tässä tutkimuksessa vapaaehtoistyöntekijät kokivat panostavansa suhteeseen antamalla apua ja aikaa sekä kuuntelevansa ikäihmisiä. Aiemmassa tutkimuksessa apua saaneet ikäihmiset taas kokivat elämänpiirinsä laajenneen ja mielialansa kohentuneen. Lisäksi he kokivat itsensä arvokkaiksi. Vapaaehtoistyöntekijät kokivat auttaneensa ikäihmisiä avartamaan arkielämäänsä ja vastaavasti ikäihmiset kokivat saaneensa mahdollisuuden tehdä normaalielämään kuuluvia asioita. Kun vapaaehtoistyöntekijät kokivat saaneensa ikäihmisiltä esimerkkiä vanhenemiseen valmentautumisessa, ikäihmiset taas ovat kokeneet antaneensa hiljaista tietoa ja esimerkkiä vanhenemisesta. Samoin tämän tutkimuksen vapaaehtoistyöntekijöiden kaksisuuntainen byväksyvä ystävyys -yläkategorian voitiin katsoa vastaavan aikaisemman tutkimuksen apua saaneiden ikäihmisten antamisen kokemusta auttajan buomioon ottaminen -yläkategoriaan (Äyräväinen ym. 2012). Näiden kahden tutkimuksen tulosten vertailu ilmensi vastavuoroisuutta ja sitä voidaan pitää odotettuna, koska tutkimusten aineistoina olivat samojen vapaaehtoistyöntekijä ja apua saanut ikäihminen -parien osapuolet. Tulosten vertailu on mahdollista, vaikka tässä jälkimmäisessä tutkimuksessa tarkasteltiin vastavuoroisuutta pelkästään sosiaalisen vaihdon teorioiden pohjalta.

Tutkimuksemme tulokset vahvistivat sosiaalisen vaihdon teoriaan pohjautuvia aikaisempia tutkimustuloksia vastavuoroisuuden tärkeydestä ikääntyneiden ihmisten sosiaalisissa suhteissa (esim. Fyrand 2010; Wahrendorf ym. 2010; Zaninotto ym. 2013; Thompson 2016; Isherwood ym. 2016). Tutkimuksemme tuloksissa ei havaittu vastavuoroisuuden epätasapainosta johtuvaa stressiä, kuten aikaisemmissa laajoissa määrällisissä tutkimuksissa (vrt. Liang ym. 2001; Wahrendorf ym. 2010; Zaninotto ym. 2013). Sen sijaan erityisesti kaksisuuntaista vastavuoroisuutta ilmentävät kohdat tiivistivät vapaaehtoissuhteen kehittymisen ja jatkumisen ominaispiirteitä. Tulosten eroa voivat selittää laadullisessa tutkimuksessa käytetyt avoimet teemat, joista haastateltavat keskustelivat. Näin vastavuoroisuudesta oli mahdollista saada esille hienovaraisempia ja monisyisempiä piirteitä.

Tämän tutkimuksen vahvuutena oli, että se oli osa interventiotutkimusta, jossa kaikki haastatellut olivat toimineet vapaaehtoistyöntekijöinä oman ulkoliikuntatoimintajaksonsa ajan ja heidät haastateltiin heti tämän kolmen kuukauden jakson jälkeen. Puhuttiin siis tietystä määritellystä vapaaehtoistyöstä, eikä muisteltu aikaisempaa osallistumista mihin tahansa vapaaehtoistoiminnaksi laskettavaan tekemiseen. Heidän kokemuksensa koskivat siis lähimenneisyydessä tapahtunutta vastavuoroisuutta, ja heidän kokemuksiaan voidaan pitää uskottavina ja tuoreina. Aineiston analyysin luotettavuutta lisäsi se, että aineistosta syntyneistä kategorioista keskusteltiin tutkijaryhmässä, jolloin ne tiivistyivät (Schreier 2012, 37-44).

Ensimmäinen kirjoittaja osallistui haastattelujen tekemisen lisäksi sekä alussa tapahtuneeseen vapaaehtoistyöntekijöiden koulutukseen että toimintajakson aikana kerran kuukaudessa pidettyihin työnohjauksellisiin tapaamisiin. Hän oli siis tavannut vapaaehtoistyöntekijöitä jo usein, minkä ansiosta haastattelut muodostuivat lämpimiksi ja turvallisiksi tilanteiksi. Kuitenkin haastattelussa käytetyt saamiseen ja antamiseen liittyvät teemat saattoivat olla liian teoreettisia ja vieraannuttaa haastateltavia todellisista kokemuksistaan vapaaehtoistyöstä. Kuten Laine $(2001,36)$ esittää, käsitteellisellä kielellä tehdyt kysymykset voivat ohjata vastaamaan käsitysten ja mielipiteiden tasolla omista kokemuksista puhumisen sijaan. Parempaan tulokseen olisi mahdollisesti päästy antamalla haastateltavien puhua vapaammin omista kokemuksistaan ilman haastattelurungon antamiseen ja saamiseen liittyviä, ehkä ehkä liian rajaavia, teemoja.

Tutkimuksemme tulokset toivat lisätietoa vastavuoroisuuden tarkasteluun osana sosiaalisen vaihdon teorioita. Ne lisäsivät ymmärrystä eläkeikäisten ihmisten vastavuoroisuuden ko- 
kemuksista. Tässä tutkimuksessa vastavuoroisuutta on käsitelty pelkästään saamisen ja antamisen vaihteluna osapuolten välillä (Gouldner 1960). Vastavuoroisuuden tutkiminen kansan uskomuksien tai moraalisten normien kannalta olisi kiinnostava lisätutkimuksen aihe. Eläkeikäiset vapaaehtoistyöntekijät kokivat sekä saavansa että antavansa toimiessaan apua saaneiden ikäihmisten kanssa toimintajaksonsa aikana. He kokivat tämän tasapainoisena vastavuoroisuutena. Kiinnostavana löytönä voidaan pitää kaksisuuntaisen vastavuoroisuuden kategorioita. Niiden kohdalla vastavuoroisuus tasapainottui välittömästi yksittäisen toiminnan aikana. Tässä tutkimuksessa nousi esiin se, kuinka tärkeässä asemassa vastavuoroisuus on työelämästä luopumisen siirtymävaiheessa, kun etsitään uusia kiinnostuksen kohteita täyttämään elämään tullutta vapaa-aikaa (vrt. Searle 1989; Auld \& Case 1997).

Tuloksemme viittaavat siihen, että eläkeikäiset vapaaehtoistyöntekijät kokivat heitä hiukan vanhempien ikäihmisten toimivan heille esimerkkeinä, tietyllä tavalla oppaina eläkkeellä olemisessa ja vanhenemiseen valmentautumisessa. Tulosten perusteella eläkeikäisten ihmisten osallistuminen heitä vanhempien,

\section{Kirjallisuus}

Auld C.J. \& Case A.J. (1997) Social exchange processes in leisure and non-leisure settings: A review and exploratory investigation. Journal of Leisure Research, 29, 183-200.

Beel-Bates C.A., Ingersoll-Dayton B. \& Nelson E. (2007) Deference as a form of reciprocity among residents in assisted living. Research on Aging 29, 626-643.

Blau P.M. (1987) Microprocess and macrostructure. Teoksessa Social exchange theory. Toim. K.S. Cook. Beverly Hills: Sage, 83-100.

von Bonsdorff M. \& Rantanen T. (2011) Benefits of formal voluntary work among older people. A review. Aging Clinical and Experimental Research 23, 162-169.

Carlson Jones D. \& Vaughan K. (1990). Close friendships among senior adults. Psychology and Aging 3, 451-457. liikkumiskyvyn ongelmista kärsivien ikäihmisten auttamiseen vapaaehtoistyönä, tarjoaa tekijöilleen paljon heidän omaa hyvinvointiaan edistäviä kokemuksia. Tällainen vapaaehtoistyö näyttää lisäävän eläkeikäisten vapaaehtoistyöntekijöiden kokemuksia mielekkäämmästä elämästä eläkkeelle siirtymisen vaiheessaan sekä kokemuksia paremmasta elämänlaadusta.

Tutkimuksen tuloksia voidaan hyödyntää tarjoamalla eläkkeelle jääville ihmisille mahdollisuuksia erilaisiin vapaaehtoistyön muotoihin, joissa he toimivat yhdessä jo kauemmin eläkkeellä olleiden vanhempien ikäihmisten kanssa. Näin vastikään eläkkeelle jääneet, uudet eläkeläiset, saavat kokemusasiantuntijoiden, iäkkäämpien ihmisten mentorointia eläkkeellä olemisesta ja vanhenemisesta kokonaisuutena. Lämpimät kiitokset LitT Marjo Kuuselalle, joka suunnitteli vapaaehtoiskoulutukseemme Toimiva vuorovaikutus -koulutuksen osuuden ja toimi kouluttajana ensimmäisillä kursseillamme.

\section{Yhteydenotto: \\ Irma Äyräväinen \\ Jyväskylän yliopisto \\ Sähköposti: irma.ayravainen@jyu.fi}

Casey J. (2014) A personal journey of volunteerism. Canadian Psychology, 55, 34-37.

Cattan M., Hogg E. \& Hardill I. (2011) Improving quality of life in ageing populations: What can volunteering do? Maturitas 70, 328-332.

Corporation for National \& Community Service, Office of Research and Policy Development. (2007) The health benefits of volunteering: a review of recent research. Washington, DC, Corporation for National \& Community Service.

Emerson R.M. (1976).Social exchange theory. Annual Review of Sociology, 2, 335-362.

Fyrand L. (2010) Reciprocity: A predictor of mental health and continuity in elderly people's relationships? A review. Current Gerontology and Geriatrics Research Article ID 340161.

Goodman C.C. (1999) Reciprocity of social support 
in long-term marriage. Journal of Mental Health and Aging 5, 341-357.

Gordon T. (2006) Toimiva koulu. Jyväskylä: Gummerus.

Gottlieb B.H. \& Gillespie A.A. (2008) Volunteerism, health, and civic engagement among older adults. Canadian Journal on Aging 27, 399-406.

Gouldner A.W. (1960) The norm of reciprocity: A preliminary statement. American Sociological Review, 25, 161-178.

Grasser C. \& Craft B.J. (2000) The blessing of giving: the importance of reciprocity to self-health care. Geriatric Nursing 21, 138-143.

Haarni I. (2010a) Eläkeikäisten kohtaamispaikat tekemisen ja tapaamisen yhteisöinä. Gerontologia 24, 3-13.

Haarni I. (2010b) Kolmas elämä: aktiiviset eläkeikäiset kaupungissa. Helsinki: Gaudeamus.

Homans G.C. (1958) Social behavior as exchange. American Journal of Sociology, 63, 597-606.

Isherwood L., Luszcz M. \& King D. (2016) Reciprocity in material and time support within parent-child relationships during late-life widowhood. Ageing E Society 36, 1668-1689.

Komp K., van Tilburg T. \& Broese van Groenou M. (2012) Age, retirement, and health as factors in volunteering in later life. Nonprofit and Voluntary Sector Quartely 41(2), 280-299.

Laine T. (2001) Miten kokemusta voidaan tutkia? Fenomenologinen näkökulma. Teoksessa J. Aaltola \& R. Valli (toim.) Ikkunoita tutkimusmetodeihin II. PS-kustannus, Jyväskylä.

Liang J., Krause N.M. \& Bennett J.M. (2001) Social exchange and well-being: is giving better than receiving? Psychology and Aging 16, 511-523.

Lumme-Sandt K. (2005) Vanhan ihmisen kohtaaminen haastattelutilanteessa. Teoksessa J. Ruusuvuori \& L. Tiittula (toim.) Haastattelu Tutkimus, tilanteet ja vuorovaikutus. Tampere: Vastapaino.

Merrell J. (2000) 'You don't do it for nothing': women's experiences of volunteering in two community Well Woman Clinics. Health and Social Care in the Community 8, 31-39.

Munn-Giddings C. \& McVicar A. (2007) Self-help groups as mutual support: what do carers value? Health E Social Care in the Community 15, 26-34.

Onyx J. \& Warburton J. (2003) Volunteering and health among older people: A review. Australasian Journal on Ageing 22, 65-69.
Rahkonen, J. (2015) Vapaaehtoistyön tekeminen Suomessa. Tutkimusraportti. Taloustutkimus Oy. http://sakasti.evl.fi/sakasti.nsf/sp?open\&ci$\mathrm{d}=$ Content $25 \mathrm{~B} 241$

Rantakokko M., Pakkala I., Äyräväinen I. \& Rantanen T. (2015) The effect of out-of-home activity intervention delivered by volunteers on depressive symptoms among older people with severe mobility limitations: a randomized controlled trial. Aging \& Mental Health 19, 231-238.

Rantanen T., Äyräväinen I., Eronen J., Lyyra T, Törmäkangas T., Vaarama M. \& Rantakokko M. (2015) The effect of an outdoor activities' intervention delivered by older volunteers on the quality of life of older people with severe mobility limitations: a randomized controlled trial. Aging Clinical Experimental Research 27, 161-169.

Roe B., Whattam M., Young H. \& Dimond M. (2001) Elders' perceptions of formal and informal care: aspects of getting and receiving help for their activities of daily living. Journal of Clinical Nursing 10, 398-405.

Sabbath E.L., Matz-Costa C., Rowe J.W., Leclerc A., Zins M., Goldberg M. \& Berkman L.F. (2016) Social Predictors of Active Life Engagement: A Time-Use Study of Young-Old French Adults. Research on Aging 38, 864-893.

Schreier M. (2012) Qualitative content analysis in practice. London: SAGE Publications Ltd.

Searle M.S. (1989) Testing the reciprocity norm in a recreation management setting. Leisure Sciences, 11,353-365.

Seitsamo J. (2007) Retirement transition and well-being. A 16-year longitudinal study. People and Work Research Reports 76. Helsinki: Finnish Institute of Occupational Health.

Thompson S. (2016) Promoting reciprocity in old age: a social work challenge. Social Work in Action 28, 341-355.

Tower R.B. \& Kasl S.V. (1996) Gender, marital closeness, and depressive symptoms in elderly couples. Journal of Gerontology: Psychological Sciences 51B, P115-P129.

Wahrendorf M., Ribet C., Zins M., Goldberg M. \& Siegrist J. (2010) Perceived reciprocity in social exchange and health functioning in early old age: prospective findings from the GAZEL study. Aging and Mental Health 14, 423-432. 
Wahrendorf M., Blane D., Matthews K. \& Siegrist J. (2016) Linking Quality of Work in Midlife to Volunteering During Retirement: A European Study. Population Ageing 9:113-130.

Wheeler J.A., Gorey K.M. \& Greenblatt B. (1998) The Beneficial Effects of volunteering for older volunteers and people they serve: a meta-analysis. The International Journal of Aging \& Human Development 47, 69-79.

Wolff J. \& Agree E.M. (2004) Depression among recipients of informal care: the effects of reciprocity, respect, and adequacy of support. Journal of Gerontology: Social Sciences 59:S173-S180.
Yeung A.B. (2004) The octagon model of volunteer motivation: results of a phenomenological analysis. Voluntas. International Journal of Voluntary and Nonprofit Organizations. 15, 21-47.

Zaninotto P., Breeze E., McMunn A. \& Nazroo J. (2013) Socially productive activities, reciprocity and well-being in early old age: gender-specific results from the English longitudinal study of ageing (ELSA). Population Ageing 6, 47-57.

Äyräväinen I., Lyyra T-M., Lintunen T. \& Rantanen T. (2012) Vastavuoroisuus ikääntyneiden ihmisten vapaaehtoistyössä apua saaneiden henkilöiden kokemana. Gerontologia 26, 172-182. 